\title{
PROVISION OF EQUAL RIGHTS AND OPPORTUNITIES RELATING WITH LABOUR RELATIONS IN PUBLIC SECTOR
}

Dalia PERKUMIENĖ, Faculty of Economics and Management, Aleksandras Stulginskis University, Studentų g. 11, Akademija, LT-53361 Kauno raj., Lithuania, perkum@gmail.com (corresponding author)

Rasa MERKIENE், Faculty of Economics and Management, Aleksandras Stulginskis University, Studentų g. 11, Akademija, LT-53361 Kauno raj., Lithuania, rasa.merkiene@ asu.lt

Ozgur OGUZ, Faculty of Law, Anadolu University Yunusemre Kampus, Ogrenci Merkezi, 26470 Eskisehir, Turkey, ooguz1@anadolu.edu.tr

\begin{abstract}
Human rights are one of the most popular topics in modern global communities. Therefore, the adoption of the Law of the Republic of Lithuania on Equal Opportunities and the establishment of the institution that governs the execution of this law is a significant legal step which permits to actually ensure the compliance of one of the most fundamental rights of the individual, i.e. nondiscrimination on the basis of gender.

Equality, being one of the fundamental principles of human rights, is governed by international contracts and legal acts of the Republic of Lithuania.

The results of the questionnaires permit to claim that the administration of Kaunas district municipality pays too little attention to the provision of the information about the Law on Equal Opportunities of the Republic of Lithuania and amendments where of to the employees of Kaunas district municipality. Thus there are a lot of problems related to the provision of equal opportunities to the employees at work.
\end{abstract}

Keywords: equal opportunities, equal rights, labour relations, employees, violation of equal opportunities.

\section{INTRODUCTION}

Each person who wants to work has the right to equal opportunities relating to labour relations. Only properly ensured equal opportunities relating to labour relations can promote efficient work in the organization and permit to achieve positive results. The provision of equal opportunities relating to labour relations to employees is regulated by various legal acts and laws. Each employee should be aware of his/her rights and opportunities relating to labour relations and how these rights and opportunities are provided. Human rights are one of the most popular topics of modern global communities. Taking care of human rights becomes a priority of internal politics of democratic states. The preamble of the Constitution of the Republic of Lithuania declares that the Lithuanian nation strives for an open, just, and harmonious civil society, while the fundamental human rights and freedoms are laid down in the Articles of the Constitution. Article 29 of the Constitution provides that human rights may not be restricted or privileges granted on the ground of gender, race, nationality, language, origin, social status, religion, convictions, or views. The aforementioned provisions comply with the requirements of international documents, which establish the necessity to protect and respect a person, his/her honour and dignity, and protect others from any discrimination.

Discrimination is a problem of the whole Europe. According to the data of the survey of the European Commission (November, 2011), about every sixth European has been personally discriminated. $64 \%$ of the Europeans fear that discrimination on the basis of age will increase due to economic decline at labour market.

The institutions of the European Union (EU) pay special attention to the fight against gender inequalities in modern society. The EU gender equality policy was basically focused on the application of equal pay in accordance with Article 119 of the Treaty of Rome until the very end of the twentieth century. Now gender equality policy is regulated by a list of directives which guarantee the assurance of wider range of gender equality rights at workplace.

Employees working in the field of sport and physical culture development, the same as those who are working in other fields, must have the right to equal opportunities relating to labour relations. Only properly ensured equal rights and opportunities relating to labour relations can promote effective work in this sector and permit to achieve positive results.

The paper aim to investigate whether equal rights and opportunities relating to labour relations are provided to the employees of Kaunas district municipality.

Copyright (C) 2015 The Authors. Published by Aleksandras Stulginskis University. This is an open-access article distributed under the terms of the Creative Commons Attribution License (CC-BY 4.0), which permits unrestricted use, distribution, and reproduction in any medium, provided the original author and source are credited. 


\section{The objectives:}

- To discuss the concept and principles of equal rights and opportunities relating to labour relations;

- To investigate how the employees of Kaunas district municipality perceive the concept of equal opportunities relating to labour relations.

Object of the research - the provision of equal rights and opportunities relating with labour relations to the employees of Kaunas district municipality.

Research methods. The following research methods have been used: analysis and generalization of scientific literature, analysis of legal acts, comparative, analytical, graphical visualization and statistical methods, questionnaire research methods ${ }^{1}$.

\section{THE CONCEPT OF THE PROVISION OF EQUAL OPPORTUNITIES RELATING TO LABOUR RELATIONS}

Equal opportunities in the international documents on human and citizen rights and the laws of the Republic of Lithuania is defined as the implementation of human rights regardless of age, sexual orientation, disability, race or ethnic origin, religion, convictions, or other bases laid down in other international contracts or laws of the Republic of Lithuania (Lietuvos..., 2003; Lithuanian Institute of Philosophy and Sociology..., 1994). The concept of equal opportunities in the laws of the Republic of Lithuania ensures equal opportunities at labour market for both women and men.

Equal opportunity is a stipulation that all people should be treated similarly, unhampered by artificial barriers or prejudices or preferences, except when particular distinctions can be explicitly justified (Paul de Vries, 2011).

Generally the terms "equality of opportunity" and "equal opportunity" are interchangeable, with occasional slight variations: "equality of opportunity" has more of a sense of being an abstract political concept, while "equal opportunity" is sometimes used as an adjective, usually in the context of employment regulations, to identify an employer, a hiring approach, or law. Equal opportunity provisions have been written into regulations and have been debated in courtrooms (Greenhouse, 2010).

Human rights are one of the most popular topics in modern global communities. Therefore, the adoption of the Law of the Republic of Lithuania on Equal Opportunities and the establishment of the institution that governs the execution of this law is a significant legal step which permits to actually ensure the compliance of one of the most fundamental rights of the individual, i.e. non-discrimination on the basis of gender (Women's Information Center..., 2000).

The laws of the Republic of Lithuania that regulate the rights of employees, legal interests and their protection methods, provide the following fundamental rights of employees: the right to work; the right to fair pay, the right to join into organizations; the right to collective negotiations; the right to occupational orientation and preparation; the right to non-discrimination; the right to information and consultation; the right to take part in the determination and improvement of the working conditions and working environment; the right against dismissal and the right in case of bankruptcy of enterprise or institution; the right to dignity at work; the right to maintain family; the right to favourable conditions at work to employees; the right to demand that the employer should ensure safety and health at work, install collective protective equipment, provide with personal protective equipment; the right to receive information from the head of the subdivision or the employer about hazardous and/or dangerous factors in their working environment; the right to have access to the results of the initial and periodic medical examinations; in case of disagreement with the examination results, undergo a repeat medical check-up; the right to authorise representative (representatives) of employees to negotiate or enter into negotiations himself with the employer about improvements in occupational safety and health; refuse to work in the event of danger to the safety and health of employees, as well as to perform work for the safe performance whereof an employee has not been trained, or when collective protective equipment is not installed or necessary personal protective equipment is not provided; claim, in accordance with the procedure established by laws, compensation for the damage to health caused by unsafe working conditions; the right to address a representative of employees, the head of the subdivision, the employer, the occupational safety and health service, the occupational safety and health committee of the enterprise, the State Labour Inspectorate or other state institution on safety and health issues (Nacionaliniai..., 2011; Vasiljeviené, 2000).

There are a lot of non-governmental organizations in Lithuania, which are working in the field of the protection of human rights. Only some of them make significant impact on the position of society, government institutions and international organizations. Government institutions insufficiently consider the activity of non-governmental organizations in the field of the protection of human rights (Nacionalinis..., 2002).

There is an ongoing debate in our society about the provision of gender equality. Equality, being one of the fundamental principles of human rights, is governed by international contracts and legal acts of the Republic of Lithuania. Equality infringing activity, i.e. discrimination, is prohibited. Therefore, the conditions for the provision and implementation of equality are aimed (Kanopienè, 1998).

Article 29 of the Constitution of the Republic of Lithuania in 1994 declared that there are open and concealed gender equality violations in Lithuania, yet Lithuanians did not notice these violations and considered discrimination as a normal life phenomenon. Article 29 of the Constitution entrenches that institutional attitude of the state towards gender discrimination has changed since 1994. Gender equality principles of the first research were entrenched in the

\footnotetext{
${ }^{1}$ A questionnaire was chosen as the most effective and convenient research method to collect data. The questionnaire was prepared for this purpose and 100 employees of Kaunas district municipality were questioned.
} 
Constitution of the Republic of Lithuania and in the Law on Employment Contract (28-11-1991). Today, we are already speaking about the Law of the Republic of Lithuania on Equal Opportunities adopted at the end of 2003 and the establishment of Equal Opportunities Ombudsman in 1999 (Purvaneckas, 2001).

The Law on Equal Opportunities for Women and Men of the Republic of Lithuania entrenches the provision that women and men have to respect each other's role in society. Each person, being a member of the society, must have equal rights regardless of gender, age, sexual orientation, disability, race or ethnic origin, religion, and must also have the right to do favourite job and receive pay, which would only depend on work quality and the level of professional skills (Purvaneckas, A., Purvaneckienè, G., 2001). Each person must have equal opportunities to seek education, professional development and career, take part in the field of culture and art.

The new Turkish Labour Code regulates labour relations starting from the "the signing of a contract of employment;" therefore, the process of "engagement" is left out of its scope. Here, it can be said that the clause on gender equality. Article 10 of the Constitution, ought to be taken into consideration. In practice, however, in the work announcements of the Turkish Employment Organization (ISKUR), whose services cover job search, placement and relocation, sex is specified in the requirements. ISKUR publicizes those announcements as it receives them, explaining that the content of them is dictated by market demands (Turkish Labour Code, Law No.4857.).

Discrimination of people is a global problem which can be expressed in various forms (direct discrimination, indirect discrimination, harassment / offence, violence) and practically in all the spheres of life.

People are most often discriminated on the basis of age and gender. Therefore, the following parts of this paper will further investigate the provision of equal rights and opportunities relating to labour relations to employees on the basis of age and gender.

Discrimination on the basis of gender is understood as unequal treatment of male and female representatives. People are most often discriminated when they want to find a job, seek career, education, etc. It should be noted that exceptional conditions for working women related to maternity protection is not considered as discrimination. According to the Law on Equal Opportunities for Women and Men, special protection of women during pregnancy, childbirth and nursing is not considered as discrimination on the basis of gender. This is not a privilege or guaranteed protection of a new society member (Lietuvos..., 1998).

There are problematic issues concerning the principle of equal treatment in access to employment both in the public and private sectors. Therefore, it is difficult to say that the Turkish legislation is congruent with the principle of equal treatment as defined in Directive 76/207/EEC ${ }^{2}$.

In Turkey there is no legislation that allows for discretionary practices in terms of promotion. Moreover, in accordance with Article 5 of the Labour Code, "in employment relationships, discrimination on the basis of considerations cannot be made." Despite this fact, it is hard to claim that the new Turkish Labour Code fully corresponds with the Directive in terms of promotion (Turkish Labour Code, 2015).

The issue of promotion of the public servants and employees is also regulated by the Act on Civil Servants, through Articles 64 to 72. The criteria of promotion include seniority right, merit, priority, position, and employment record. However, it should be noted that there are no women in the rank of undersecretary of state. It can be claimed that, despite the lack of any provision hindering the promotion of women in legal terms, there is a kind of inequality that can be considered as indirect discrimination. Therefore, it is questionable whether there is complete congruence with the Directive ${ }^{3}$.

According to the Article 50 of the Turkish Constitution, no one shall be required to perform work unsuited to his age, sex, and capacity. With this law, women and children enjoy special protection with regard to working conditions. The basic legal provisions regarding the protection of women in the labour market are regulated by Article 5(3) of the Labour Code. According to the law, if there are no specific points that hinder working conditions such as biological factors or the characteristics of the job, an employer may not treat workers differently, directly or indirectly, in closing a business contract, or deciding, implementing and terminating an employment contract, on the basis of pregnancy and/or gender (Taymaz, E., \& Özler, Ş. (2004; Pekin\&Pekin. (2009). The sanctions against the employer in case of discrimination are also indicated in the Labour Code. On the other hand, the number of women who can enjoy such security is very limited because of the restrictions defined in the law. Accordingly, the security applies to an employee who is engaged for an indefinite period, who is employed in an establishment with thirty or more workers and who meets a minimum seniority of six months ${ }^{4}$.

Article 50 of the Constitution concerning working conditions and the right to rest and leisure states that no person may be employed in a job that is unsuited to his/her age, sex and ability. According to the law, children and women shall be specially protected in terms of work conditions. In Turkish legislation, there are a number of regulations related to the protection of women, especially pregnant women and mothers, the most important of which are contained in the new Labour Code. With the new regulations, women are granted further rights and the requirements of Council Directive 92/85/EEC are met to a significant extent. However, it is difficult to claim that the new legislation contains all regulations corresponding to the Directive. Despite changes that have already been brought to the labour

\footnotetext{
2 Toprak, Binnaz and Ersin Kalaycioglu, The Woman in Work Life, Upper-Level Management, and Politics (Istanbul: Turkish Economic and Social Studies Foundation (TESEV) Publications, May 2004).

${ }^{3}$ N. Sural, Avrupa Topluluğunun Çalışma Yasamında Kadın Erkek Eşitliğine Dair Düzenlemeleri ve Turkiye (Ankara: KSSGM Yayınlar1, 2001), p. 175.

${ }^{4}$ Kenar Necdet, İ̧̧ Yaşamı ve Mesleki Eğitim Açısından Meslek Standartları, Sınav ve Sertifikasyon Sisteminin Önemi (Nisan: TíSK İşveren Dergisi, 2002).
} 
laws, there is a lack of sufficient guarantees in terms of the equality of women and men, especially concerning pregnant and nursing women. Women continue to face discrimination in employment to varying degrees ${ }^{5}$.

Unequal opportunities can be noticed in pay, rise of qualification, professional career, etc. Inequality (discrimination) of people who are making and/or planning to make a family as well as employment opportunities of women are still highly conditioned by stereotypical attitude towards social role of women and men (Blom, R. 1997).

Discrimination on the basis of age is a special treatment to someone closely related with certain attitudes towards a person, i.e. age norms and age stereotypes (Featherstone and Wernick, 1995, Nelson, 2002; Dipboye and Colella, 2005; Ageism, 2006). The latter phenomenon, i.e. preconceived attitude towards a person on the basis of his/her age, is called ageism (with analogy with racism and sexism) in the Anglo-Saxon literature.

Demographic characteristics, i.e. gender and age, of future employees plays a very important role in the requirements of employers. The requirements regarding appearance and age are still prevailing (every forth work advertisement included age requirement, while the limit of 35-year-old was the most "popular". Moreover, employers often required even much younger employers). Knowledge of foreign language and computer skills are most often demanded from employees (Kanopienè, 1998). It should be also highlighted that age has significant meaning during employment: the younger applicant for a job is, the greater chances to be employed he/she has.

Equal opportunities are often differently perceived in various countries: racial, gender or ethnic attitudes are emphasized. Racial inequality, which was in the centre of attention earlier, concedes its leading positions to the problems of equal opportunities on the basis of gender.

The $858^{\text {th }}$ meeting of the Committee of Ministers of the Council of Europe has ascertained that achievements of Lithuania in ensuring equality for women and men are very well evaluated among 45 European countries. Lithuania, the same as Sweden, is enlisted as good practice country having assessed the following criteria: acting national equality mechanisms, participation and collaboration of non-governmental organizations, enhancing gender equality policies, protection against compulsion, fight against women trafficking (Miller, 2005).

The institutions of the European Union are currently actively working in the field of fighting against discrimination and are seeking validation of equal opportunities in the EU countries. The website of the Employment and Social Affairs of the European Commission permits to get a complete picture on the scope of activities: the EU publishes newsletters, brochures, posters, statistics summaries on discrimination and the provision of equal opportunities, teaching material on non-discrimination issues, expert assessment reports on the achievements of fighting against discrimination in the member states, national reports on the formation of the base of anti-discrimination legal acts, various research reports, etc. (European..., 2011).

\section{QUESTIONNAIRE RESEARCH OF THE EMPLOYEES OF KAUNAS DISTRICT MUNICIPALITY}

The research aimed to investigate how the employees of Kaunas district municipality perceive the concept of equal opportunities relating to labour relations and to find out whether they are satisfied with the provision of equal opportunities at the workplace.

Several methods could have been used to collect data about the provision of equal opportunities relating to labour relations in Kaunas district municipality. A questionnaire was chosen as the most effective and convenient research method to collect data. The questionnaire was prepared for this purpose and 100 employees of Kaunas district municipality were questioned. The survey was conducted from January to April, 2015.

With regard to the question whether respondents understand the concept of equal opportunities at labour market, $(55.8 \%)$ respondents said they understand the concept, $(25.6 \%)$ respondents said they understand the concept partially and $(18.6 \%)$ respondents said they do not understand the concept. The results are graphically depicted in Fig. $1^{6}$.

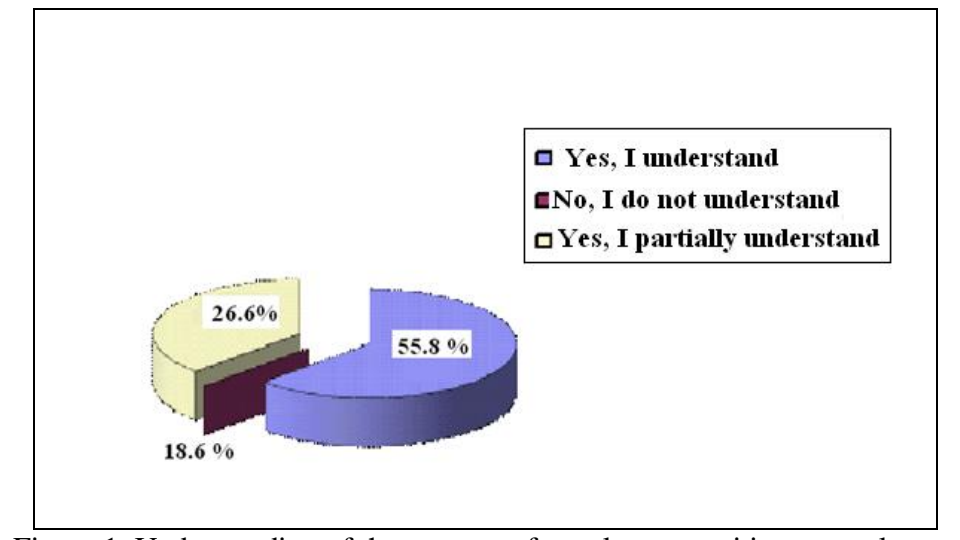

Figure 1. Understanding of the concept of equal opportunities to employees

\footnotetext{
${ }^{5}$ Fevziye Sayılan, Eğitim Sektöründe Kadınların Durumu, Women’s Status in the Educational Sector. Ankara: Eğitim-Sen Yayınları, 2003.

${ }^{6}$ According to the survey of analysis data. 100 employees of Kaunas district municipality were questioned.
} 
With regard to the question how respondents understand the concept of equal opportunities, $37.2 \%$ respondents said that the concept of equal opportunities refers to the provision of human rights entrenched in the laws of the Republic of Lithuania, 39.5\% respondents said that the concept of equal opportunities refers to the assurance of equal conditions at work, while none of the respondents $(0 \%)$ explained the concept of equal opportunities otherwise (ticked 'other').

Having asked the opinion of employees whether the right to equal opportunities is violated at their workplace, $30.3 \%$ respondents said that they think that the right to equal opportunities is violated, $48.8 \%$ respondents said that the right to equal opportunities are not violated and $11.6 \%$ respondents do not know whether the right to equal opportunities is violated at their workplace or not, while $9.3 \%$ respondents had no opinion on this question.

The employees of Kaunas district municipality have been asked where violation of equal opportunities occurs. Having processed the collected data, the following results were received: the right to equal opportunities on the basis of gender was violated for $13.9 \%$ employees of Kaunas district municipality, the right to equal opportunities on the basis of age was violated for $25.6 \%$ employees, the right to equal opportunities on the basis of disability was violated for $6.9 \%$ employees, the right to equal opportunities on the basis of sexual orientation was violated for $2.3 \%$ employees and $4.6 \%$ employees said that equal opportunities were violated on the basis of race and ethnic origin, while answers regarding violations of equal opportunities on other basis have not been received. These results permit to suppose that the level of violation of equal rights on the basis of gender is rather high in Kaunas district municipality.

The results of the question whether the respondents are satisfied with the provision of equal opportunities at the workplace are depicted in Figure $2^{7}$.

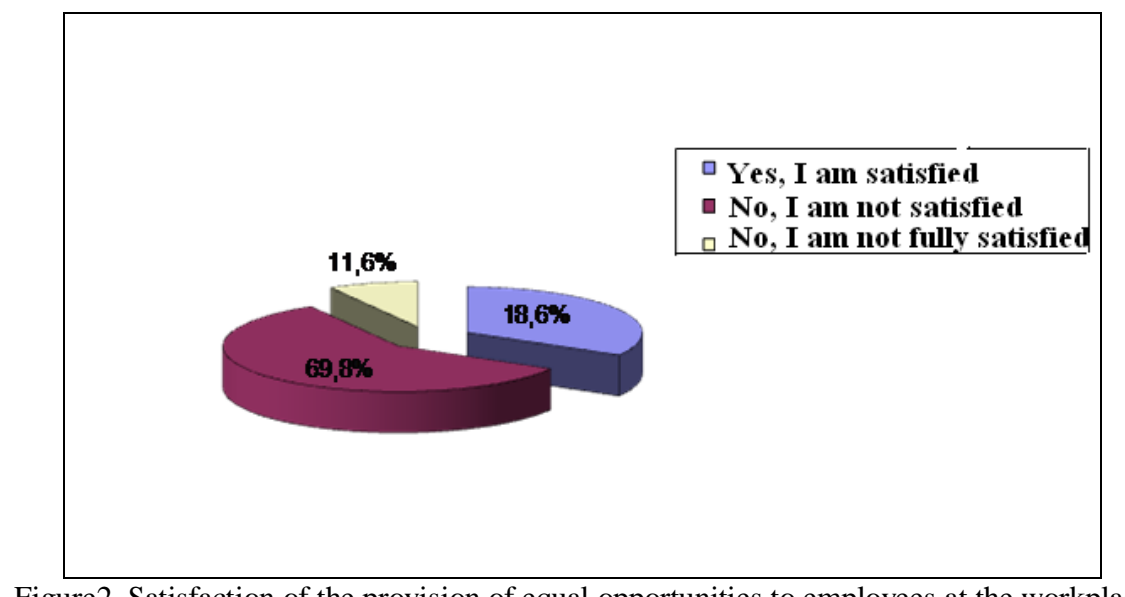

Figure2. Satisfaction of the provision of equal opportunities to employees at the workplace

In order to find out how the administration of Kaunas district municipality implements the provision of equal opportunities at workplace and service sector, respondents have submitted the following answers: $30.2 \%$ respondents said that the organization provides information on the provisions of legal acts of the Republic of Lithuania regarding equal opportunities and non-discrimination, $2.3 \%$ respondents said that there is a person who is in charge of the issues regarding the provision of equal opportunities, $53.6 \%$ respondents said they have certain knowledge about legal acts, but official policy document in this field has not yet been developed, while $13.9 \%$ respondents have chosen the answer 'other'.

The data of the research permits to make a conclusion that the majority of the employees of Kaunas district municipality think that gender equality does not exist.

The questionnaire included the following question: who, men or women, can raise professional carrier easier. The following results to this question have been received: $55.8 \%$ respondents think that men can raise their professional career easier, $2.3 \%$ respondents said that women can do that easier, while $41.9 \%$ respondents think that both men and women can raise their professional career easy.

Table 1 presents the opinion of respondents how equal opportunities should be provided at work.

Table $1^{8}$. Opinion of employees about the provision of equal opportunities at work

\begin{tabular}{|l|c|}
\hline \multicolumn{1}{|c|}{ Measures } & Percent \\
\hline Equal work load & 20.9 \\
\hline Equal pay regardless of gender & 44.1 \\
\hline Gender equality in labour relations & 34.9 \\
\hline Equal opportunities for improvement and qualification raising & 48.8 \\
\hline Promotion of job position regardless of gender, age and other factors & 27.9 \\
\hline Other & 1 \\
\hline
\end{tabular}

\footnotetext{
${ }^{7}$ According to the survey of analysis data. 100 employees of Kaunas district municipality were questioned.

${ }^{8}$ According to the survey of analysis data. 100 employees of Kaunas district municipality were questioned.
} 
The provision of equal opportunities relating to labour relations to the employees of Kaunas district municipality is possible under the following circumstances: sufficient financial resources, sincere attempts of employees to perform his/her duties are good as possible, goodwill and awareness of the employees and the management of the centre in creation of safe, cosy working environment and optimal working conditions.

\section{CONCLUSIONS}

1. Equality, being one of the fundamental principles of human rights, is governed by international contracts and legal acts of the Republic of Lithuania. Equality infringing activity, i.e. discrimination, is prohibited. Therefore, the conditions for the provision and implementation of equality are aimed.

2. Equal opportunities are often differently perceived in various countries: racial, gender or ethnic attitudes are emphasized.

3. The situation of equal opportunities relating to labour relations is similar in various countries, including Lithuania, i.e. unequal opportunities relating to labour relations is one of the biggest problems.

4. The results of the questionnaires permit to claim that the administration of Kaunas district municipality pays too little attention to the provision of the information about the Law on Equal Opportunities of the Republic of Lithuania and amendments whereof to the employees of Kaunas district municipality. Thus there are a lot of problems related to the provision of equal opportunities to the employees at work.

5. The majority of the employees of Kaunas district municipality understand the concept of equal opportunities and only some employees do not understand this concept. A periodic surveys of employees should be carried out (since new employees are employed and it is not clear whether they understand the concept of equal opportunities), which would help to decide whether the employees understand the concept of equal opportunities. If the surveys revealed that the employees understand the concept partially, the management of the municipality should take certain measures (provide information during meetings) in order to ensure equal opportunities relating to labour relations.

6. In order to ensure equal opportunities, the following appropriate measures should be undertaken: organization of pedagogical and/or psychological seminars, consultations with lawyers, corporate trips, discussions, etc.

\section{REFERENCES}

1. Lietuvos filosofijos ir sociologijos institutas, Lietuvos šeima, Mokslinès - politinès konferencijos, Lietuvos šeima: tradicijos ir ateitis" Vilniuje 1994 m. spalio 25-26 d. (In Lithuania)

2. Lietuvos Respublikos nutarimas "dèl valstybinès moterų ir vyrų lygių galimybių 2003-2004 metų programos patvirtinimo, 2003 m. birželio 3 d. Nr. 712 Vilnius. (In Lithuania).

3. Purvaneckas, A., Purvaneckienè, G., 2001. Moteris Lietuvos visuomenëje (Palyginamoji analizè). Vilnius: Danielius. (In Lithuania).

4. Moterų informacijos centras, Moterys Lietuvoje. Vilnius, 2000. (In Lithuania)

5. Kanopienè, V. 1998. Moterų diskriminacija darbo rinkoje. Vilnius: Vilniaus universiteto leidykla. (In Lithuania)

6. Lietuvos Respublikos lygių galimybių ịstatymas, 2003 m. lapkričio 18 d. Nr. IX - 1826, Vilnius (In Lithuania).

7. Blom, R. 1997. Expert Interviews From The Baltic States, Working papers, B: 37, Department of Sociology University of Tampere, Finland, 1997.

8. Vasiljeviené, N. 2000. Verslo etika ir elgesio kodeksai. Kaunas - VU, KHF leidykla. (In Lithuania).

9. Lygiu galimybių Kontrolieriaus tarnybos $2010 \mathrm{~m}$. ataskaita. (accessed on 2015/04/12). Available at: http://www.teisingumas.lt/naujienos/siandien/zmogaus-teisiu-komitetas-svarste-lygiu-galimybiu-kontrolieriaus-tarnybos-2010m-ataskaita. (In Lithuania).

10. Kenar Necdet, İş Yaşamı ve Mesleki Eğitim Açısından Meslek Standartları, Sınav ve Sertifikasyon Sisteminin Önemi (Nisan: TİSK İşveren Dergisi, 2002. (In Turkish)

11. Sayılan, F., Sektöründe E., Durumu, K. Women's Status in the Educational Sector. Ankara: Eğitim-Sen Yayınları, 2003.

12. Toprak, Binnaz and Ersin Kalaycioglu. 2004. The Woman in Work Life, Upper-Level Management, and Politics. Istanbul: Turkish Economic and Social Studies Foundation (TESEV) Publications.

13. Sural, N. 2001. Avrupa Topluluğunun Çalışma Yasamında Kadın Erkek Eşitliğine Dair Düzenlemeleri ve Turkiye. Ankara: KSSGM Yayınları, p. 175.

14. Turkish Labour Code. Law No.4857. Available at: http://turkishlaborlaw.com/turkish-labor-law-no-4857/19-4857-labor-lawenglish-by-article.

15. Turkish Constitution. https://global.tbmm.gov.tr/docs/constitution_en.pdf. July 23, 1995; Act No. 4121.

16. Pekin\&Pekin. 2009. Memorandum regarding the overview of the turkish labor code (law no. 4857). Retrieved fromhttp://www.seelegal.org/upload/documents/Turkey/Overview_of_the_Turkish_Labour_Code_(Law_No_4857-_April_2009.pdf.

17. Taymaz, E., Özler, Ş. 2004. Labor market policies and eu accession: Problems and prospects for Turkey. ERC Working Papers in Economic, 04(04). Available at: http://www.erc.metu.edu.tr/menu/series04/0405.pdf.

18. de Vries, P. 2011. Equal opportunity. NJ: Princeton University Press.

19. Greenhouse, S. 2010. "E.E.O.C. Sues Kaplan Over Hiring".The New York Times. (accessed on 2015/09/08). 